\title{
EFFECTS OF MIXED CONTROLLED RELEASE AND NORMAL UREA ON MAIZE (ZEA MAYS L) GROWTH, GRAIN YIELD AND NITROGEN BALANCE AND USE EFFICIENCY IN NORTHEAST CHINA
}

\author{
LI, C. L. ${ }^{1,2}-$ CAO, Y. Q. ${ }^{1,2}-$ WANG, Y., ${ }^{1,2}-$ LI, X. Y. ${ }^{1,2}-$ LI, Y. X. ${ }^{1,2}-$ ZHU, L. ${ }^{1,2}-$ ZHAO, X. H. ${ }^{1,2}$ \\ $-\mathrm{GAO}, \mathrm{Q}{ }^{1,2}$ \\ ${ }^{1}$ College of Resources and Environmental Science, Jilin Agricultural University, Changchun \\ 130118, China
}

${ }^{2}$ Key Laboratory of Soil Resource Sustainable Utilization for Jilin Province Commodity Grain Bases, Changchun, China

${ }^{*}$ Corresponding author

e-mail:wy1986410@163.com (Dr. Yin Wang)

(Received $18^{\text {th }}$ Feb 2020; accepted $2^{\text {nd }}$ Jul 2020)

\begin{abstract}
Mixed application of controlled release urea (CRU) and normal urea (NU) are effective $\mathrm{N}$ fertilization plural to improve crop yield and nitrogen use efficiency (NUE). In this study, field experiments were conducted for two consecutive years in 2018 and 2019 on two contrasting soil types. The treatments included one solely NU and four mixture ratios of CRU and NU under an identical $\mathrm{N}$ rate of $180 \mathrm{~kg} \mathrm{~N} \mathrm{ha}^{-1}$ as single basal fertilizer before sowing. The results showed that the highest maize yields were obtained from the CRU30\% treatment, increasing by $24 \%$ on sandy soil and $11 \%$ on clay soil as compared to CRU0\% treatment. The yield improvements were mainly attributed to increased seed setting percentage and grain numbers per ear. Maize plants grown in CRU30\% treatment accumulated more dry biomass (DM) and N uptake after silking, and thereby increasing grain yield and NUE. This work demonstrates that the appropriate mixture of CRU and NU increases maize yield and NUE while reducing $\mathrm{N}$ loss, by optimizing $\mathrm{N}$ fertilizer release and soil $\mathrm{N}$ availability to match the crop $\mathrm{N}$ demand, and $30 \% \mathrm{CRU}$ and $70 \% \mathrm{NU}$ was determined as the optimal mixture ratio on both sandy and clay soils in Northeast China.
\end{abstract}

Keywords: maize, controlled release urea, grain yield, $N$ uptake, DM accumulation, $N$ loss

Abbreviations. AE, agronomic efficiency; CRU, controlled release urea; CRU0\%, 100\% normal urea as basal fertilizer; CRU15\% (30\%,45\% and 60\%), $15 \%$ (30\%,45\% and 60\%) of CRU was mixed application with normal urea as basal fertilizer; DM, dry biomass; K, potassium; NU, normal urea; NUE, N use efficiency; P, phosphorus; PFP, partial factor productivity; RE, recovery efficiency

\section{Introduction}

Global food demand is expected to double by 2050 due to rapid population growth (Tilman et al., 2011). Considering the limited expansion of cultivated land area, it is essential to increase crop yield per unit cultivated land area and thereby enhance the total productivity (Burney et al., 2010; Cui et al., 2013). In the past few decades, crop yields were considerably increased by applying mass inorganic fertilizers in the intensive cropping system in China and many other countries (Chen et al., 2014). However, excessive $\mathrm{N}$ input reduced $\mathrm{N}$ use efficiency (NUE) (Cassman et al., 2002), and also adversely affected surface water, groundwater and the atmosphere through runoff, $\mathrm{N}$ leaching and reactive gaseous N emission (Drecht et al., 2003; Galloway et al., 2008; Cui et al., 2013). Therefore, further optimal $\mathrm{N}$ management practices are required in intensive 
crop production to synchronously achieve food security, higher NUE and lower environmental impacts (Guo et al., 2016).

Maize is an important crop for food and feed, has surpassed wheat and rice as the largest cereal crop in China and the whole world (FAD, 2017). Northeast China is the most important maize cropping region, accounting for $31.5 \%$ and $32.8 \%$ of the national maize planting area and production, respectively (China Agriculture Press, 2018). Traditionally, all $\mathrm{N}$ fertilizers are applied by local farmers for maize as single basal fertilizer before sowing, thus always causing mass $\mathrm{N}$ loss at the early stage and reduced final yield and NUE (Gao et al., 2012). In the local best $\mathrm{N}$ management method, split $\mathrm{N}$ fertilization (i.e. $40 \%$ as basal fertilizer and $60 \%$ as topdressing at jointing stage) is recommended to meet maize N demand for improving yield and NUE (Gao et al., 2012; Yan et al., 2016). However, the topdressing is generally unacceptable by farmers due to the operational inconvenience and high labor cost. Moreover, the split fertilization method is facing more challenges with the aging of the population and continually increasing labor cost in China (Liu and Griffiths, 2011).

Controlled release urea (CRU) is a new type of $\mathrm{N}$ fertilizer, which is designed and produced to control $\mathrm{N}$ release process for matching crop $\mathrm{N}$ demand during the growing period, has been widely used for various crops in many countries (Song et al., 2014). CRU is usually prepared by encapsulating water-soluble granular urea with a lowpermeability hydrophobic membrane, and the key principle is using a physical barrier to reduce $\mathrm{N}$ dissolution rate (Shavit et al., 1997). Numerous researchers have found that the application of CRU effectively improved maize yield and NUE (Haderlein et al., 2001; Kondo et al., 2005; Sun et al., 2010; Geng et al., 2016; Zheng et al., 2016), and reduced nitrate leaching and $\mathrm{N}$ loss (Shoji et al., 2001; Zvomuya et al., 2003), as compared to the normal urea (NU) application. However, the use of CRU for cereal crops is generally limited because of its expensive prices (Shaviv, 2001). Therefore, some researchers proposed to apply the mixture of CRU and NU with an appropriate ratio, to provide an optimal N supply for crop demand to reduce N loss, improve NUE and also decreased $\mathrm{N}$ fertilizer costs (Noellsch et al., 2009; Zheng et al., 2016; Guo et al., 2017). The optimal ratio of CRU for maize differed at various countries or regions due to the differences in soil and climate conditions, crop yield level and growth duration, which was determined as $70 \%$ at $180 \mathrm{~kg} \mathrm{~N} \mathrm{ha}^{-1}$ or $30 \%$ at $240 \mathrm{~kg} \mathrm{~N} \mathrm{ha}^{-1}$ in North China, and $70 \%$ at $180 \mathrm{~kg} \mathrm{~N} \mathrm{ha}^{-1}$ in Brazil (Guo et al., 2017; Garcia et al., 2018).

The mixed application of CRU and NUE is a promising alternative to farmers' practice of one-time fertilization and recommended split $\mathrm{N}$ fertilization in Northeast China, however, the optimal mixture ratio of CRU and NU is still not clear for local maize production. Therefore, in this study, consecutive two-year field experiments were conducted at two contrasting soil types in Northeast China, the $\mathrm{N}$ release rate of CRU in soil, the dynamics changes of maize plant dry biomass (DM) and $\mathrm{N}$ uptake, grain yields and yield components, $\mathrm{N}$ balance and loss in soil-plant system were investigated. The objectives of this study were: to investigate the possibility of mixed application of CRU and NU to synchronize the nutrient release with maize $\mathrm{N}$ uptake demand and to determine the optimal mixture ratio at different soil types in Northeast China. The results would provide new $\mathrm{N}$ management techniques to achieve higher maize yield and NUE with lower environmental impacts. 


$$
\text { - } 5369 \text { - }
$$

\section{Materials and Methods}

\section{Experiment site description}

Field experiments were conducted in 2018 and 2019 at two sites in Jilin Province,

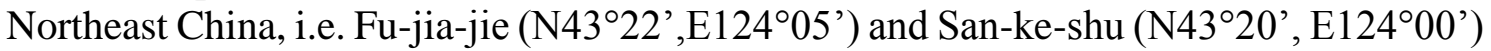
(Figure 1). The two sites are only $4 \mathrm{~km}$ away from each other, and have the nearly identical meteorological condition (Feng et al., 2019). The experimental region is located in the warm-temperate and has a semi-humid continental monsoon climate with a hot and rainy summer and a cold and dry winter, and the annual precipitation ranges between 400 and $600 \mathrm{~mm}$. The detailed daily average temperature and rainfall during the maize growing season are shown in Figure 2. The total precipitation showed significant difference between two experimental years, which was $354.5 \mathrm{~mm}$ in 2018 and $533.4 \mathrm{~mm}$ in 2019. Obviously, the climate was drier in 2018 as compared with 2019, especially during sowing and seed germination in spring (May and June).

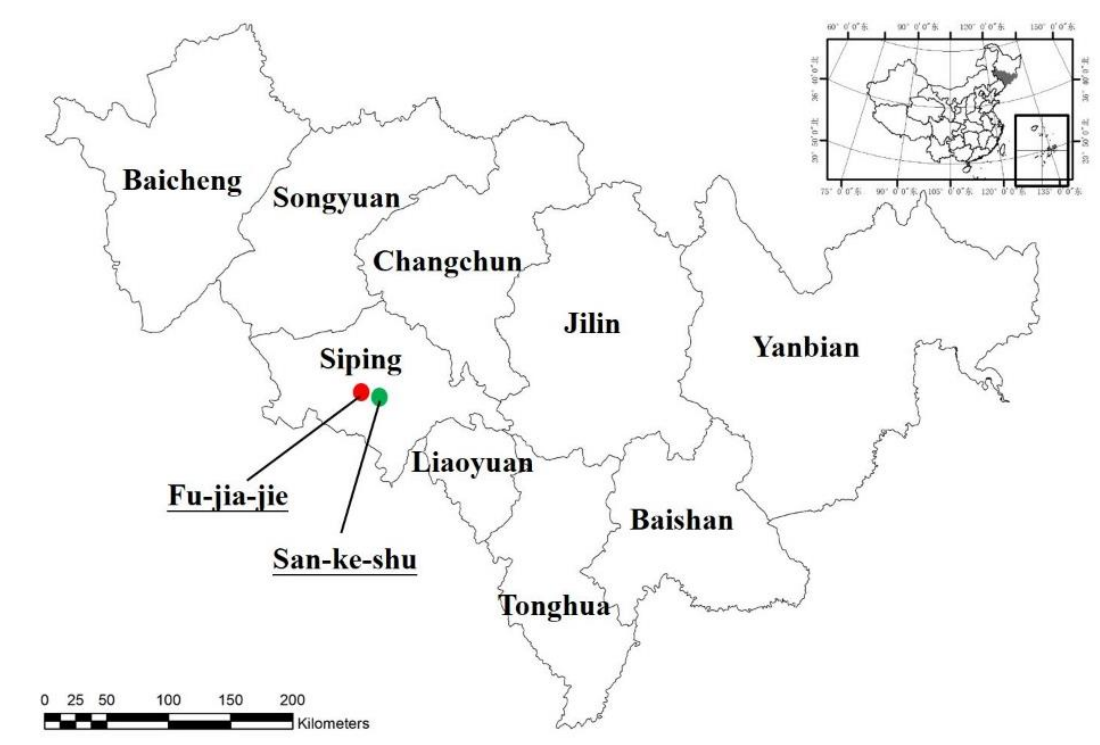

Figure 1. Distribution of experimental site in the Fu-jia-jie and San-ke-shu, Jilin province, Northeast China

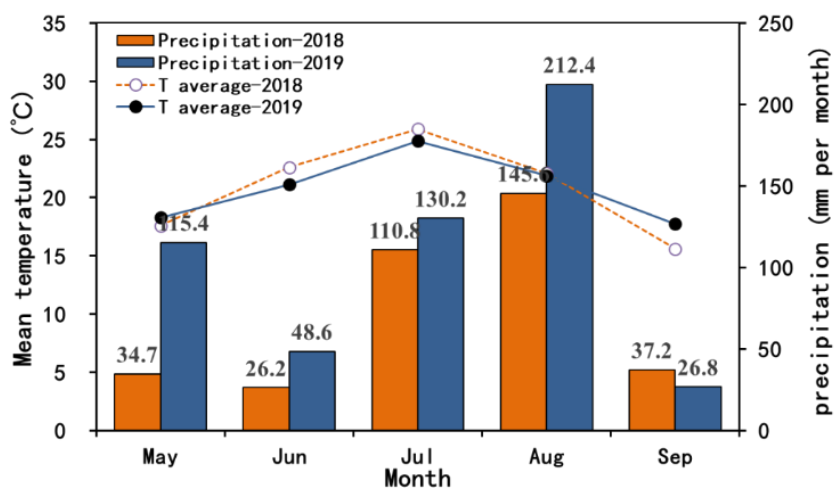

Figure 2. Daily average temperatures $\left({ }^{\circ} \mathrm{C}\right)$ and precipitation $(\mathrm{mm})$ during the maize growing seasons in 2018 and 2019. The numbers above the bars indicate the total precipitation in the corresponding months 


$$
-5370-
$$

The soils in Fu-jia-jie and San-ke-shu are classified as Aeolian sandy soil and Black soil, respectively, according to the Chinese Soil Taxonomy (CRGCST, 2001). The soil texture in Fu-jia-jie is sandy soil with $79.6 \%$ sand, $9.6 \%$ silt, and $10.8 \%$ clay, and the main properties of topsoil layer $(0-20 \mathrm{~cm})$ are: $\mathrm{pH} 6.04$, organic matter $12.4 \mathrm{~g} \mathrm{~kg}^{-1}$, total $\mathrm{N} 0.81 \mathrm{~g} \mathrm{~kg}^{-1}, \mathrm{NO}_{3}^{-}-\mathrm{N} 13.92 \mathrm{mg} \mathrm{kg}^{-1}, \mathrm{NH}_{4}{ }^{+}-\mathrm{N} 9.22 \mathrm{mg} \mathrm{kg}^{-1}$, available P $24.9 \mathrm{mg} \mathrm{kg}^{-1}$ and available K $93.2 \mathrm{mg} \mathrm{kg}^{-1}$. While the soil texture in San-ke-shu is clay soil with $32.5 \%$ sand, $25.2 \%$ silt, and $42.3 \%$ clay, and the main properties of topsoil layer are: $\mathrm{pH} 5.58$, organic matter $30.1 \mathrm{~g} \mathrm{~kg}^{-1}$, total $\mathrm{N} 2.09 \mathrm{~g} \mathrm{~kg}^{-1}, \mathrm{NO}_{3}^{-}-\mathrm{N} 26.11 \mathrm{mg} \mathrm{kg}{ }^{-1}, \mathrm{NH}_{4}^{+}-\mathrm{N}$ $14.1 \mathrm{mg} \mathrm{kg}^{-1}$, available $\mathrm{P} 40.1 \mathrm{mg} \mathrm{kg}^{-1}$ and available $\mathrm{K} 142.5 \mathrm{mg} \mathrm{kg}^{-1}$.

\section{Experimental design and field management}

Each field experiment consisted of six $\mathrm{N}$ treatments with three replications: N0 (without N fertilizer), CRU0 (100\% NU), CRU15\% (15\% N CRU mixed with 85\%NU), CRU30\% (30\%N CRU mixed with 70\%NU), CRU45\% (45\%N CRU mixed with 55\% $\mathrm{NU})$ and CRU60\% (60\% N CRU mixed with 40\%NU). In N fertilization treatments, all the $\mathrm{N}$ fertilizers were one-time applied before sowing at $185 \mathrm{~kg} \mathrm{ha}^{-1}(\mathrm{~N})$. Across all the treatments, $\mathrm{P}$ and $\mathrm{K}$ fertilizers were also one-time applied before sowing at $87 \mathrm{~kg} \mathrm{ha}^{-1}$ $\left(\mathrm{P}_{2} \mathrm{O}_{5}\right)$ and $90 \mathrm{~kg} \mathrm{ha}^{-1}\left(\mathrm{~K}_{2} \mathrm{O}\right)$, respectively. Conventional fertilizers used in this study included NU $(46 \% \mathrm{~N})$, calcium superphosphate $\left(16 \% \mathrm{P}_{2} \mathrm{O}_{5}\right)$ and potassium chloride $\left(60 \% \mathrm{~K}_{2} \mathrm{O}\right)$. The CRU, manufactured by Shandong Maoshi Ecological fertilizer Inc, Dezhou, China, is a polymer-coated urea with a N content of $44 \%$.

Field experiment was a completely randomized block design with a total of 18 plots in each site, and the plot size was $48 \mathrm{~m}^{2}(6 \times 8 \mathrm{~m})$. Maize variety Liangyu 99 , a widely cultivated variety in Northeast China, was sown in early May (May 9 and 5 in 2018 and 2019, respectively) and harvested in early October (October 3 both in 2018 and 2019). Plant density was 65,000 plants ha ${ }^{-1}$ with a $60 \mathrm{~cm}$ space between rows across the sites and years. In both two years, the weeds, diseases and pests were well controlled as needed according to the local best management practice, and no irrigation was done during the entire growing seasons.

\section{Sampling and chemical analyses}

Plant samples were collected at the seedling stage (V5-V6), jointing stage (V12), silking stage (R1), grain filling stage (R3) and physiological maturity stage (R6), i.e. 27, 46, 79, 109 and 140 days after sowing (DAS) in both years. Five adjacent maize plants were sampled in each plot and separated into stems (including leaf sheath, tassel and cob), leaves (including leaves and bracts) and grains, and then dried to the constant weights at $70^{\circ} \mathrm{C}$ for determining DM. Dried plant samples were ground to powder for further determining $\mathrm{N}$ concentration by $\mathrm{H}_{2} \mathrm{SO}_{4}-\mathrm{H}_{2} \mathrm{O}_{2}$ digestion and the micro-Kjeldahl procedure (Douglas et al., 1980). At physiological maturity, grain yield was manually harvested from an area of $18 \mathrm{~m}^{2}(3.6$ by $5 \mathrm{~m})$ in the middle of each plot and standardized to a moisture content of $15.5 \%$.

Recovery efficiency $\left(\mathrm{RE}_{\mathrm{N}}\right)$, agronomic efficiency $\left(\mathrm{AE}_{\mathrm{N}}\right)$ and partial factor productivity $\left(\mathrm{PFP}_{\mathrm{N}}\right)$ of $\mathrm{N}$ fertilizer were calculated using equations (1), (2) and (3) below (Dobermann, 2007).

$$
\begin{gathered}
\mathrm{RE}_{\mathrm{N}}=\left(\mathrm{U}-\mathrm{U}_{0}\right) / \mathrm{N} \times 100 \\
\mathrm{AE}_{\mathrm{N}}=\left(\mathrm{Y}_{\mathrm{N}}-\mathrm{Y}_{0}\right) / \mathrm{N}
\end{gathered}
$$




$$
-5371-
$$

$$
\mathrm{PFP}_{\mathrm{N}}=\mathrm{Y}_{\mathrm{N}} / \mathrm{N}
$$

where $\mathrm{N}$ is the $\mathrm{N}$ fertilizer rate $\left(\mathrm{kg} \mathrm{ha}^{-1}\right), \mathrm{U}_{0}$ and $\mathrm{U}$ are the plant $\mathrm{N}$ uptake $\left(\mathrm{kg} \mathrm{ha}^{-1}\right)$ at maturity in $\mathrm{N}_{0}$ and $\mathrm{N}$ fertilization treatments, respectively, $\mathrm{Y}_{0}$ and $\mathrm{Y}_{\mathrm{N}}$ are the grain yield $\left(\mathrm{kg} \mathrm{ha}^{-1}\right.$ ) at maturity in $\mathrm{N}_{0}$ and $\mathrm{N}$ fertilization treatments, respectively.

Basic soil sample was collected randomly from 0 to $20 \mathrm{~cm}$ soil layer in each site before tillage, to analyze physical and chemical properties followed the soil testing methods of Page et al. (1982). In addition, fresh soil samples were also collected randomly at $0-100 \mathrm{~cm}$ in each plot with a $20-\mathrm{cm}$ increments by using an auger, before sowing and after harvest in each year. These soil sample were extracted with $100 \mathrm{ml} 0.01 \mathrm{M} \mathrm{CaCl}_{2}$ to analyze soil $\mathrm{NO}_{3}{ }^{-}-\mathrm{N}$ and $\mathrm{NH}_{4}{ }^{+}-\mathrm{N}$ contents using Continuous Flow Analysis (AA3 Auto Analyzer system, Seal Analytical $\mathrm{GmbH}$, Norderstedt, Germany). During the maize growing seasons, the amounts of apparent soil $\mathrm{N}$ mineralization $\left(\mathrm{kg} \mathrm{ha}^{-1}\right)$ and $\mathrm{N}$ loss $\left(\mathrm{kg} \mathrm{ha}^{-1}\right)$ were calculated according to the balance methods described by Guo et al. (2017).

\section{Test of CRU release in the field}

The $\mathrm{N}$ release rate of CRU was tested in field condition with a buried bag method (Kaneta et al., 1994). Before fertilization, $10.0 \mathrm{~g}$ of CRU was accurately weighed and placed in small nylon net bags $(15 \times 10 \mathrm{~cm})$ with $150 \mathrm{~cm}^{2}$ mesh size. In each site, a total of 24 CRU fertilizers bags were buried in no-fertilized areas neighboring the experimental plots while fertilization, and three bags were collected each time at 2, 5, 7, 21, 42, 70, 105 and 140 days after burial. After sampled bags were opened with scissors, CRU granules were removed and rinsed with distilled water to remove the attached soil, and then placed in a vacuum oven at $60^{\circ} \mathrm{C}$ for $48 \mathrm{~h}$ to obtain the constant weight for determination of the $\mathrm{N}$ release rate from CRU (Kaneta et al., 1994; Guo et al., 2017).

\section{Statistical analyses}

All data across the $\mathrm{N}$ treatments, soil types and years were pooled for analysis of variance (ANOVA) with a three-factor analysis program by using the SAS statistical analysis package (version 9.4, SAS Institute, Cary, NC, USA). The least significant difference test (LSD) was performed to compare the differences among $\mathrm{N}$ treatments at the $5 \%$ significance level.

\section{Results}

\section{$C R U$ release in the field conditions}

The $\mathrm{N}$ release curves from CRU were significantly affected by experimental years and soil types (Figure 3). On average, total $\mathrm{N}$ release amounts of CRU during the maize growing seasons were $83.9 \%$ and $90.8 \%$ in 2018 and 2019, respectively. $\mathrm{N}$ release from CRU was severely limited due to the rainless climate in 2018. The CRU granules had similar total $\mathrm{N}$ release amounts on sandy and clay soils, with the averages of $86.7 \%$ and $88.0 \%$, respectively, but they showed contrasting release processes between soil types. In 2018, about $20 \%$ of N was released at 42 and 28 days on sand and clay soils, respectively, and the durations for $80 \%$ of $\mathrm{N}$ release were 116 and 98 days, respectively. In 2019, about $20 \%$ of $\mathrm{N}$ was released at 20 and 15 days on sand and clay soils, respectively, and the durations for $80 \%$ of $\mathrm{N}$ released were 79 and 71 days. Obviously, $\mathrm{N}$ release from CRU was slowed on sandy soil as compared with clay soil, especially under the adverse climatic condition. 


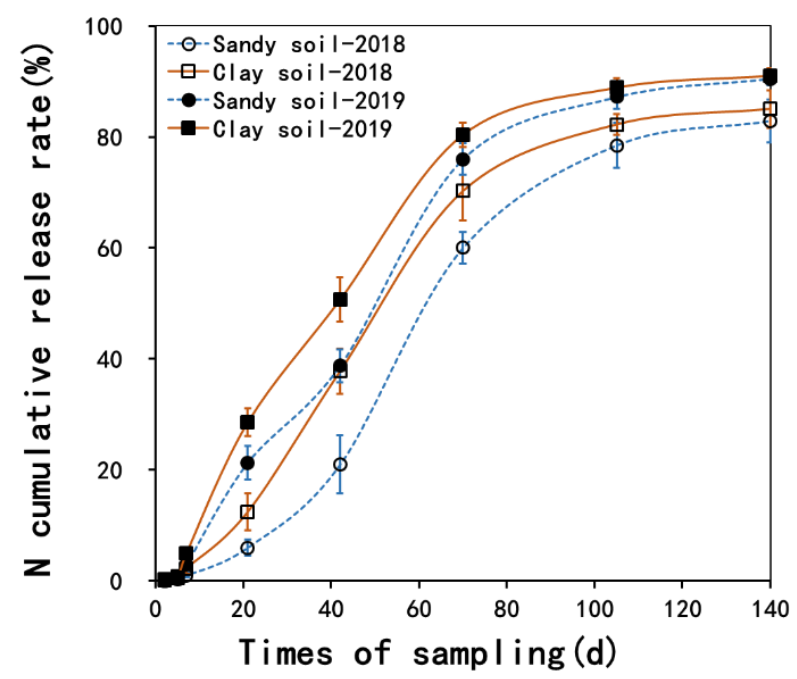

Figure 3. Nitrogen release curves of controlled release urea in field conditions in 2018 and 2019. The vertical bars indicate standard error of the mean in the nitrogen release curves

\section{Maize yield and yield components}

Maize yield was significantly affected by soil type, year, $\mathrm{N}$ treatment, and all the two-factor interactions (Table 1). In 2018, across the different $\mathrm{N}$ treatments, the average maize yield was $11.3 \mathrm{t} \mathrm{ha}^{-1}$ on clay soil, which was $36.7 \%$ higher than that of $8.3 \mathrm{t} \mathrm{ha}^{-1}$ on sandy soil. In 2019, the average yield was $13.2 \mathrm{t} \mathrm{ha}^{-1}$ on clay soil and which was $19.0 \%$ higher than that of $11.1 \mathrm{t} \mathrm{ha}^{-1}$ on sandy soil. Obviously, maize yields were limited on sandy soil as compared with clay soil, especially under the rainless climate in 2018. Across the soil types and years, maize yields were increased with $\mathrm{N}$ fertilizers application relative to N0 treatment, and those in mixed CRU treatments were as or higher than that in CRU0\% treatment. The CRU30\% treatment showed the highest yields with an average of $12.6 \mathrm{tha}^{-1}$, but had no significant differences with other mixed CRU treatments except for CRU60\% treatment on sandy soil in 2018. Compared with CRU0\% treatment, the yield increase in CRU30\% treatment was $27.6 \%$ in 2018 and $21.3 \%$ in 2019 on sandy soil, respectively, and those were $11.1 \%$ and $11.3 \%$ on clay soil, respectively.

In terms of yield components, all the parameters were better for plants grown on clay soil as compared with sandy soil, and which were better in 2019 than those in 2018. Among the different $\mathrm{N}$ fertilization treatments, no significant differences were observed in seed setting percentage and 100-grain weight on clay soil, while grain numbers per ear was higher in all mixed CRU treatments as compared with CRU0\% treatment. In contrary, the responses of yield components to $\mathrm{N}$ treatments were greater on sandy soil, all the parameters were affected by $\mathrm{N}$ fertilization treatments except for the seed setting percentage in 2019. Compared with CRU30\% treatment, CRU0\% treatment showed the lowest parameters and followed by CRU60\% treatment on sandy soil, while other mixed ratio treatments had no significant differences. The increases of yield components in CRU30\% treatment was $5.5 \%$ for seed setting percentage, $10.4 \%$ for grain numbers per ear and $9.6 \%$ for 100-grain weight in 2018, respectively, relative to CRU0\% treatment; and these increases were $2.0 \%, 6.4 \%$ and $8.3 \%$ in 2019. 


$$
\text { - } 5373-
$$

Table 1. Maize yield and yield components as affected by $N$ treatments and soil types in 2018 and 2019

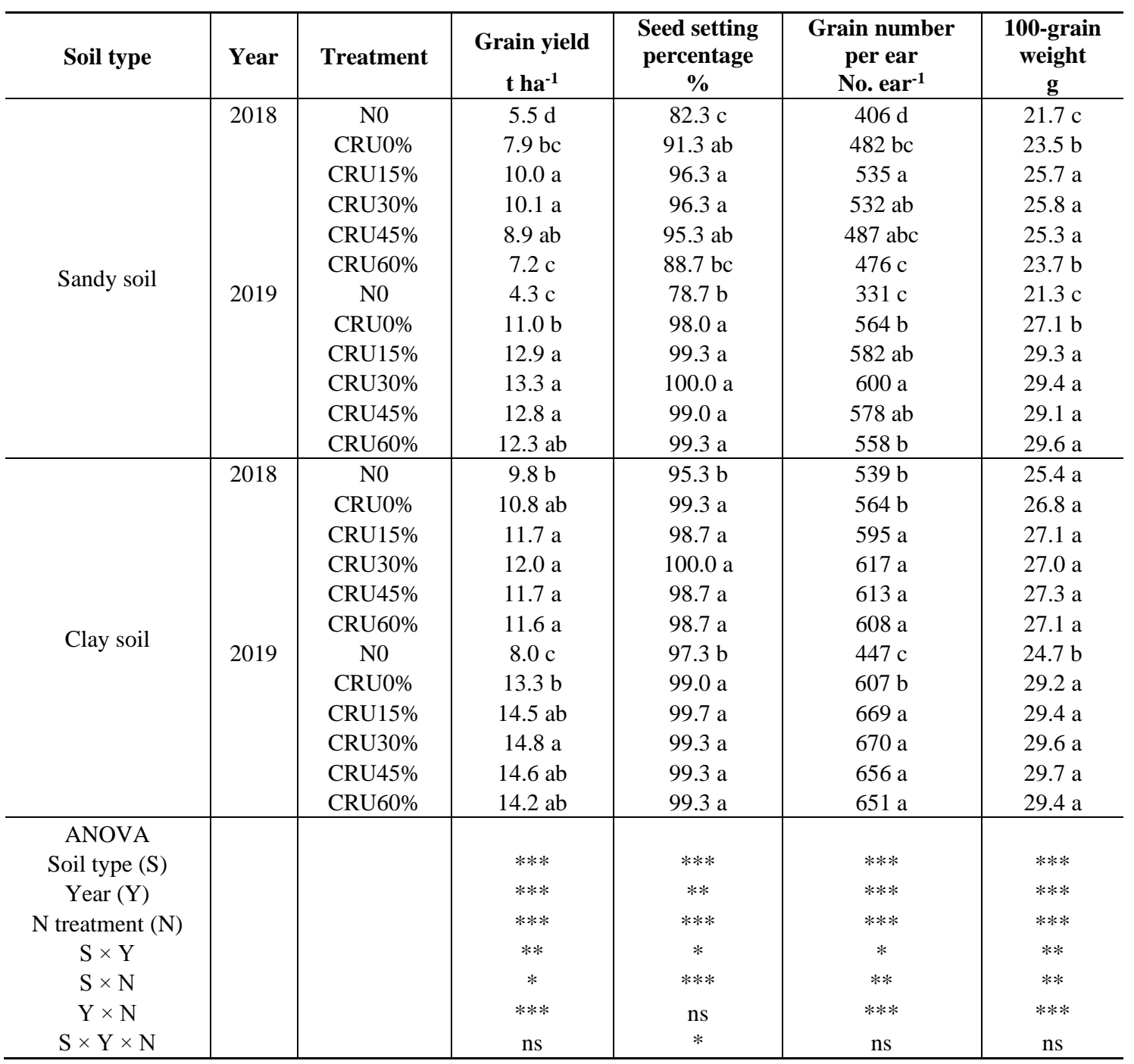

Means within each column, soil type and year followed by different letters are significantly different at $\mathrm{P}=0.05$. ns, no significant; * significant at $\mathrm{p}<0.05 ;{ }^{* *}$ significant at $\mathrm{p}<0.01 ; * * *$ Significant at $\mathrm{p}<0.001$

Hence, mixed application of CRU and NU could effectively improve maize yield as compared with sole NU application, and showed better performance in yield improvements on sandy soil, even under the adverse climatic condition in 2018. The best yield improvements in CRU30\% treatment could be attributed to the dramatically increased grain numbers per ear and 100-grain weight, in combination with a slightly enhanced seed setting percentage.

\section{Plant DM accumulation}

The total DM of maize plants at maturity was obviously lower in 2018 than 2019, mainly associated with the limited DM accumulation at seedling stage (Figure 4). On average, the total DMs were 18.9 and $13.8 \mathrm{t} \mathrm{ha}^{-1}$ on clay and sandy soils in 2018, respectively, while which were 21.6 and $16.8 \mathrm{t} \mathrm{ha}^{-1}$ in 2019 , respectively. Compared with sandy soil, maize plants grown on clay soil accumulated $37.4 \%$ and $28.9 \%$ more total DM 


$$
-5374 \text { - }
$$

in the two years, respectively. During the entire maize growing season, plant DM accumulation was lower in N0 treatment than $\mathrm{N}$ fertilization treatments across the soil types and years, and the DM gaps enlarged obviously in 2019 due to the continuous soil $\mathrm{N}$ consumption. Compared with CRU0\% treatment, higher total DMs at maturity were observed in all the mixed CRU treatments except for CRU60\% on sandy soil in 2018. Plant DM accumulation had no difference between the treatments with or without CRU at the vegetative growth periods, thus the differences in total DMs at maturity were attributed to the different DM accumulation after silking. Obviously, the post-silking DM percentages in the mixed CRU treatments were higher than those in CRU0\% treatment under the most soil and climate conditions, especially in CRU30\% treatment (Figure 5).
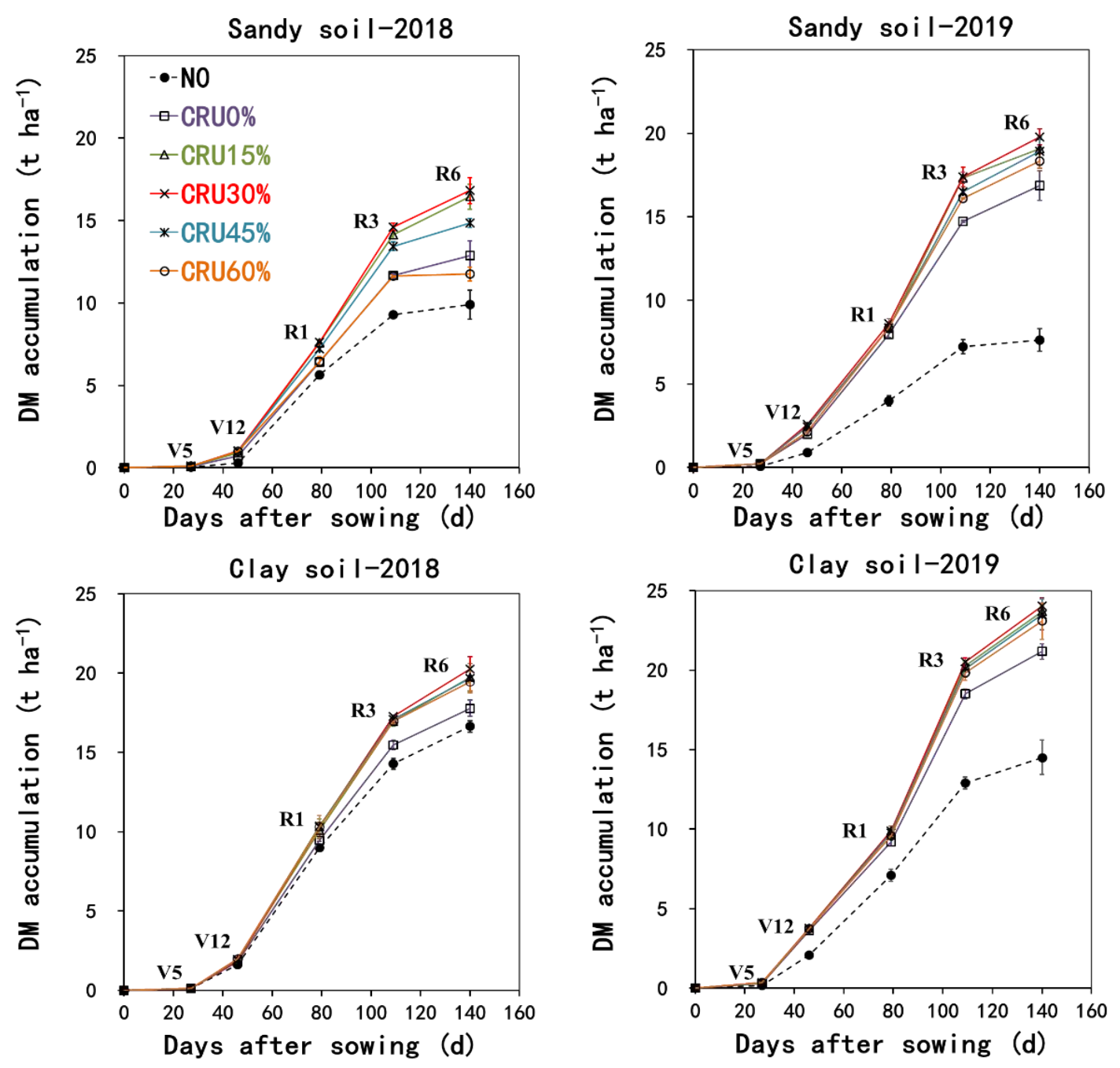

Figure 4. DM accumulation dynamic of maize plants as affected by $N$ treatments and soil types in 2018 and 2019. The vertical bars indicate standard error of the mean

Across the soil types and years, no differences were observed in plant DM accumulation among the mixed CRU treatments during the maize growing seasons, except for sandy soil in 2018 (Figure 4). On average, CRU30\% treatment showed the highest total DM at maturity of $20.2 \mathrm{t} \mathrm{ha}^{-1}$, and followed by CRU15\% (19.7 $\left.\mathrm{t} \mathrm{ha}^{-1}\right), \mathrm{CRU}$ 


$$
-5375-
$$

45\% (19.2 $\left.\mathrm{t} \mathrm{ha}^{-1}\right)$ and CRU60\% (18.2 $\left.\mathrm{tha}^{-1}\right)$. In 2018, the total DMs in CRU30\% treatment were $30.7 \%$ and $17.3 \%$ higher than those in CRU0\% treatment on sandy and clay soils, respectively, and the increases were $14.0 \%$ and $13.5 \%$ in 2019, respectively. Mixed application of CRU and NU showed greater improvements in plant DM accumulation on sandy soil as compared with clay soil, especially under rainless climate in 2018.

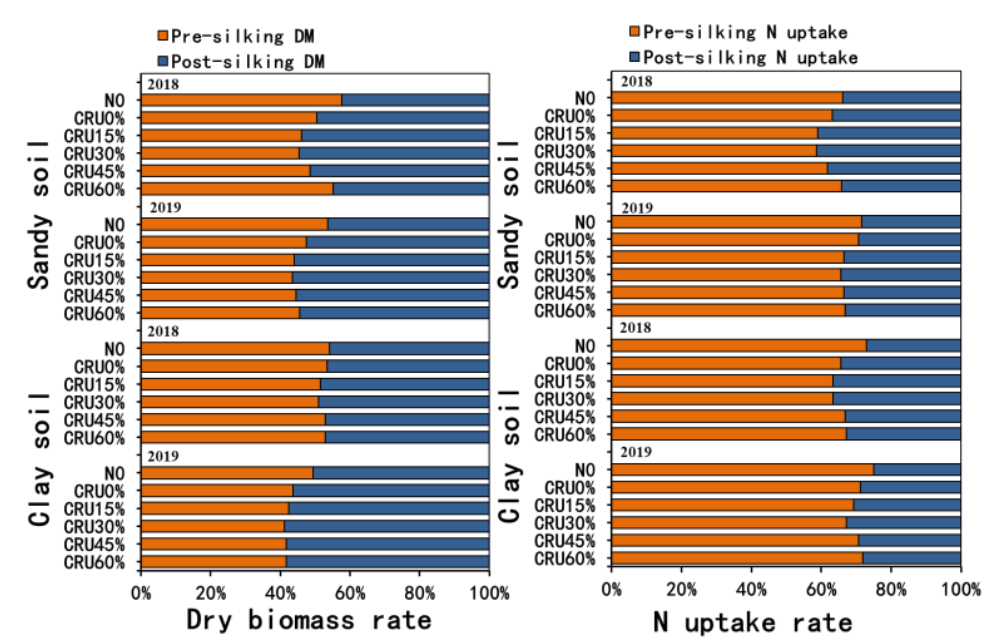

Figure 5. The pre-and post-silking percentages of plant DM and $N$ uptake for maize as affected by $N$ treatments and soil types in 2018 and 2019

\section{Plant N uptake}

The $\mathrm{N}$ uptake of maize plants showed similar responses to soil types, inter-annual climate and $\mathrm{N}$ treatments, as compared with plant DM accumulation (Figure 6). On average, the total $\mathrm{N}$ uptakes at maturity were 131.1 and $183.3 \mathrm{~kg} \mathrm{ha}^{-1}$ in 2018 and 2019 on clay soil, respectively, which were $47.7 \%$ and $29.4 \%$ higher than those of 88.7 and $141.7 \mathrm{~kg} \mathrm{ha}^{-1}$ on sandy soil, respectively. The $\mathrm{N}$ uptakes were obviously reduced by adverse soil and climatic conditions. Compared with plant DM, plant $\mathrm{N}$ uptake suffered greater limitation by $\mathrm{N}$ deficiency in the N0 treatment, which showed significant differences with $\mathrm{N}$ fertilization treatments at silking stage (R1) on clay soil in 2018 and at seedling stage (V5) in the other conditions. Compared with CRU0\% treatment, higher total $\mathrm{N}$ uptakes at maturity were observed in all the mixed CRU treatments except for CRU60\% on sandy soil in 2018. The differences in N uptake became significant since the late vegetative stage (V12) between the treatments with or without CRU. Moreover, the pre- and post-silking $\mathrm{N}$ uptake also showed obvious differences between these treatments (Figure 5). The post-silking N uptake percentages were higher in CRU30\% and CRU15\% treatments, as compared with other $\mathrm{N}$ fertilization treatments.

In both two years, no differences were observed in total $\mathrm{N}$ uptakes among the mixed CRU treatments on clay soil. However, these mixed CRU treatments showed different total $\mathrm{N}$ uptakes on sandy soil especially in 2018. Overall, the highest $\mathrm{N}$ uptake was obtained in CRU30\% treatment, and followed by CRU15\% treatment. The average $\mathrm{N}$ uptake in CRU30\% treatment were 141.6 and $179.1 \mathrm{~kg} \mathrm{ha}^{-1}$ on sandy and clay soils, respectively, which were $24.3 \%$ and $19.8 \%$ higher than those in CRU0\% treatment. Therefore, mixed CRU and NU at an appropriate ratio could improve plant $\mathrm{N}$ uptake, while the sole NU application or the over-mixture of CRU resulted in counterproductive effects. 


$$
-5376-
$$
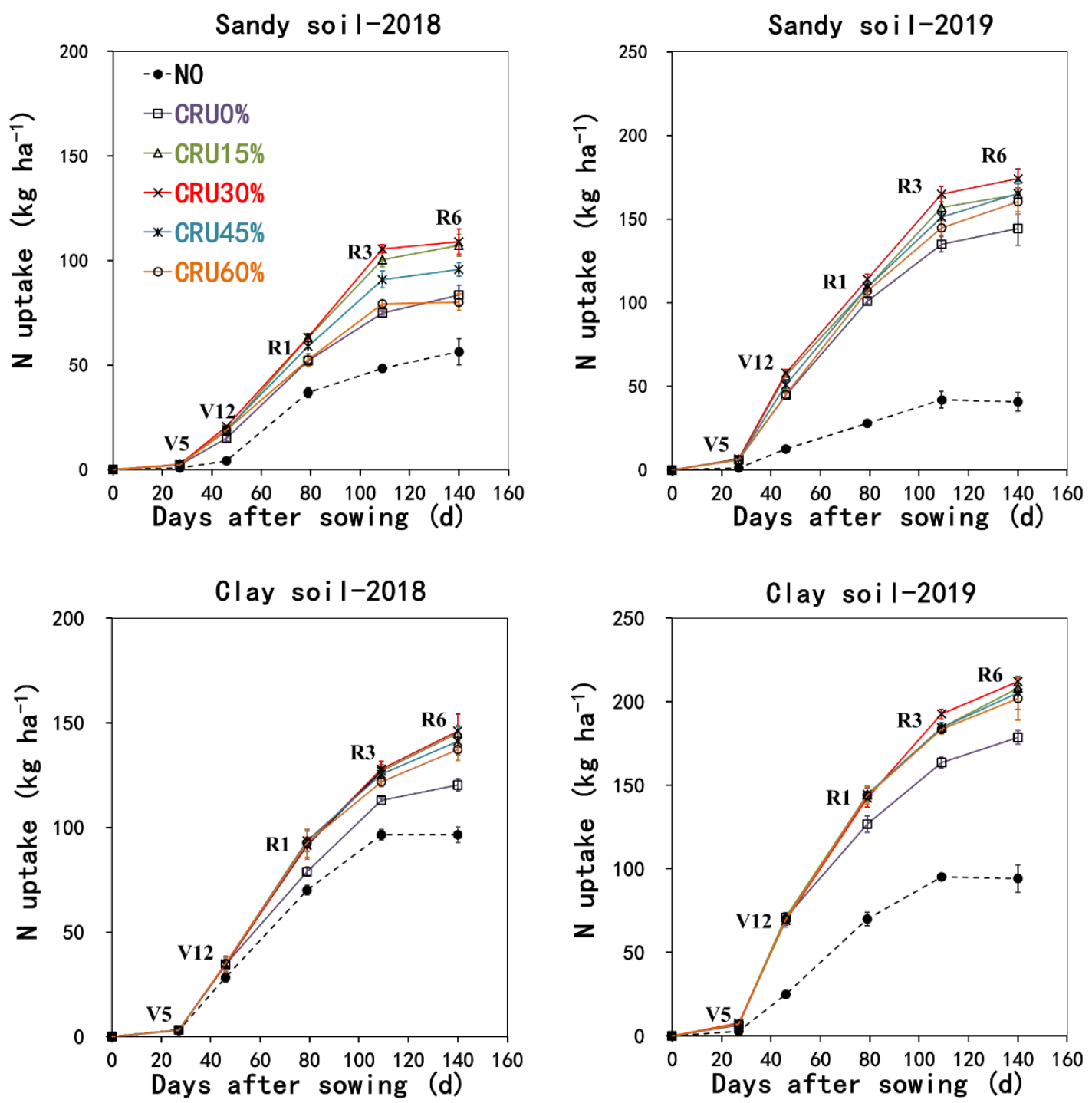

Figure 6. $N$ uptake dynamic of maize plants as affected by $N$ treatments and soil types in 2018 and 2019. The vertical bars indicate standard error of the mean

\section{Nitrogen balance and loss}

The $\mathrm{N}$ balance and apparent $\mathrm{N}$ loss were estimated based on the difference between $\mathrm{N}$ inputs and outputs in the soil-plant system, and all the related parameters were affected by soil type, year and $\mathrm{N}$ treatments (Table 2). The initial soil Nmin contents were much lower on sandy soil than clay soil. In both two years, soil $\mathrm{N}$ mineralization were also considerably less on sandy soil, and the total mineralization amounts was only $40 \%$ of that on clay soil. In contrary, $\mathrm{N}$ losses were higher on sandy soil as compared with clay soil. On average, the total $\mathrm{N}$ loss were $180.8 \mathrm{~kg} \mathrm{ha}^{-1}$ across years and $\mathrm{N}$ treatments on sandy soil, which were $8.0 \%$ higher than that of $167.4 \mathrm{~kg} \mathrm{ha}^{-1}$ on clay soil. Between experimental years, soil N mineralization of sandy soil was higher in 2018 than 2019, but which showed opposite trends on clay soil. While $\mathrm{N}$ losses showed consistent trends between soil types, both of which were obviously higher in 2018 than 2019. 
Table 2. Nitrogen balance $\left(\mathrm{kg} \mathrm{N} \mathrm{ha}^{-1}\right)$ as affected by $\mathrm{N}$ treatments and soil types in 2018 and 2019

\begin{tabular}{|c|c|c|c|c|c|c|c|c|c|c|c|c|c|}
\hline \multirow[b]{2}{*}{ Years } & \multirow[b]{2}{*}{$\mathrm{N}$ balance parameter } & \multicolumn{6}{|c|}{ Sandy soil } & \multicolumn{6}{|c|}{ Clay soil } \\
\hline & & No & $\underset{\%}{\text { CRUO }}$ & \begin{tabular}{|c|} 
CRU15 \\
$\%$
\end{tabular} & $\begin{array}{c}\text { CRU30 } \\
\%\end{array}$ & $\begin{array}{c}\text { CRU45 } \\
\%\end{array}$ & $\begin{array}{c}\text { CRU60 } \\
\%\end{array}$ & No & $\begin{array}{c}\text { CRU } \\
\text { 0\% }\end{array}$ & $\begin{array}{c}\text { CRU15 } \\
\%\end{array}$ & $\begin{array}{c}\text { CRU30 } \\
\%\end{array}$ & $\begin{array}{c}\text { CRU45 } \\
\%\end{array}$ & $\begin{array}{c}\text { CRU60 } \\
\%\end{array}$ \\
\hline \multirow{6}{*}{2018} & $\begin{array}{c}\text { A. } \mathrm{N} \text { input } \\
\text { (1) } \mathrm{N} \text { fertilizer }\end{array}$ & 0 & 185 & 185 & 185 & 185 & 185 & 0 & 185 & 185 & 185 & 185 & 185 \\
\hline & $\begin{array}{l}\text { (2) Soil Nmin before } \\
\text { sowing }\end{array}$ & 73 & 73 & 73 & 73 & 73 & 73 & 155 & 155 & 155 & 155 & 155 & 155 \\
\hline & $\begin{array}{l}\text { (3) Apparent soil } \mathrm{N} \\
\text { mineralization } \\
\text { B. N output }\end{array}$ & 36 & 36 & 36 & 36 & 36 & 36 & 59 & 59 & 59 & 59 & 59 & 59 \\
\hline & (1) Plant N uptake & 56 & 84 & 10 & 109 & 9 & 80 & 96 & 120 & 145 & 146 & 141 & 137 \\
\hline & (2) Soil Nmin at harvest & 53 & 64 & 69 & 75 & 77 & 85 & 118 & 145 & 145 & 147 & 141 & 142 \\
\hline & C. Apparent N loss: A-B & 0 & 146 & 118 & 110 & 121 & 129 & 0 & 134 & 109 & 106 & 117 & 120 \\
\hline \multirow{6}{*}{2019} & $\begin{array}{l}\text { A. } \mathrm{N} \text { input } \\
\text { (1) } \mathrm{N} \text { fertilizer }\end{array}$ & 0 & 185 & 185 & 185 & 185 & 185 & 0 & 185 & 185 & 185 & 185 & 185 \\
\hline & $\begin{array}{l}\text { (2) Soil Nmin before } \\
\text { sowing }\end{array}$ & 51 & 62 & 70 & 75 & 81 & 84 & 121 & 147 & 157 & 154 & 147 & 150 \\
\hline & $\begin{array}{l}\text { (3) Apparent soil } \mathrm{N} \\
\text { mineralization } \\
\text { B. N output }\end{array}$ & 24 & 24 & 24 & 24 & 24 & 24 & 82 & 82 & 82 & 82 & 82 & 82 \\
\hline & (1) Plant N uptake & 41 & 144 & 165 & 174 & 165 & 161 & 102 & 179 & 208 & 212 & 205 & 202 \\
\hline & (2) Soil Nmin at harvest & 34 & 47 & 63 & 65 & 72 & 69 & 101 & 149 & 162 & 166 & 165 & 171 \\
\hline & C. Apparent N loss: A-B & 0 & 80 & 51 & 45 & 53 & 63 & 0 & 86 & 54 & 43 & 44 & 44 \\
\hline \multirow{6}{*}{$\begin{array}{l}2018- \\
2019\end{array}$} & $\begin{array}{c}\text { A. } \mathrm{N} \text { input } \\
\text { (1) } \mathrm{N} \text { fertilizer }\end{array}$ & 0 & 370 & 370 & 370 & 370 & 370 & 0 & 370 & 370 & 370 & 370 & 370 \\
\hline & $\begin{array}{l}\text { (2) Soil Nmin before } \\
\text { sowing }\end{array}$ & 73 & 73 & 73 & 73 & 73 & 73 & 155 & 155 & 155 & 155 & 155 & 155 \\
\hline & $\begin{array}{l}\text { (3) Apparent soil } \mathrm{N} \\
\text { mineralization } \\
\text { B. N output }\end{array}$ & 58 & 58 & 58 & 58 & 58 & 58 & 144 & 144 & 144 & 144 & 144 & 144 \\
\hline & (1) Plant N uptake & 97 & 228 & 272 & 283 & 261 & 241 & 198 & 299 & 353 & 358 & 346 & 339 \\
\hline & (2) Soil Nmin at harvest & 34 & 47 & 63 & 65 & 72 & 69 & 101 & 149 & 162 & 166 & 165 & 171 \\
\hline & C. Apparent $\mathrm{N}$ loss: A-B & 0 & 226 & 166 & 153 & 168 & 191 & 0 & 221 & 154 & 145 & 158 & 159 \\
\hline
\end{tabular}

After consecutive two cropping seasons, soil Nmin contents in all $\mathrm{N}$ fertilization treatments showed decreasing trends on sandy soil, and the largest reduction of $35.6 \%$ was observed in CRU0\% treatment, which were considerably higher than those of $1.4 \%-13.7 \%$ in the mixed CRU treatments. In contrary, soil Nmin contents increased by $4.5-10.3 \%$ in the mixed CRU treatments on clay soil, while only decreased by $3.9 \%$ in CRU0\% treatment. Regardless of soil types and years, the N losses in CRU0\% treatment were significantly higher than those in the mixed CRU treatments, and the lowest values were observed in CRU30\% treatment. Compared with CRU0\% treatment, total N loss in CRU30\% treatment reduced by $32.3 \%$ and $34.4 \%$ on sandy and clay soils, respectively.

\section{Nitrogen use efficiency}

All the soil type, year, and $\mathrm{N}$ treatment factors showed significant individual effects on the NUE parameters, except for the $\mathrm{RE}_{\mathrm{N}}$ response to soil type (Table 3). Between experimental years, the $\mathrm{RE}_{\mathrm{N}}, \mathrm{AE}_{\mathrm{N}}$ and $\mathrm{PFP}_{\mathrm{N}}$ were significantly higher in 2019 than 2018. Between soil types, sandy soil showed higher $\mathrm{AE}_{\mathrm{N}}$ but lower $\mathrm{PFP}_{\mathrm{N}}$ as compared with clay soil. Among the $\mathrm{N}$ fertilization treatments, the highest $\mathrm{RE}_{\mathrm{N}}, \mathrm{AE}_{\mathrm{N}}$ and $\mathrm{PFP}_{\mathrm{N}}$ were observed in CRU30\% treatment, and all of which were significantly higher than those in CRU0\% treatment. Across the two years, the average $\mathrm{RE}_{\mathrm{N}}, \mathrm{AE}_{\mathrm{N}}$ and $\mathrm{PFP}_{\mathrm{N}}$ in $\mathrm{CRU} 30 \%$ treatment 


$$
\text { - } 5378 \text { - }
$$

were $50.3 \%, 36.7 \mathrm{~kg} \mathrm{~kg}^{-1}$ and $63.1 \mathrm{~kg} \mathrm{~kg}^{-1}$ on sandy soil, which were $42.4 \%, 49.9 \%$ and $24.0 \%$ higher than those in CRU0\% treatment; the average $\mathrm{RE}_{\mathrm{N}}, \mathrm{AE}_{\mathrm{N}}$ and PFP $\mathrm{N}$ in CRU $30 \%$ treatment were $45.3 \%, 24.3 \mathrm{~kg} \mathrm{~kg}^{-1}$ and $72.6 \mathrm{~kg} \mathrm{~kg}^{-1}$ on clay soil, which were $54.6 \%$, $42.9 \%$ and $11.2 \%$ higher than those in CRU0\% treatment. The NUE parameters in other mixed CRU treatments showed no differences with CRU30\% treatment, except for CRU60\% treatment on sandy soil. In addition, the significant soil type $\times$ year interaction indicated that the responses of REN and $\mathrm{PFP}_{\mathrm{N}}$ to soil types were affected by inter-annual climatic conditions, their gaps between years were larger on sandy soil as compared with clay soil.

Table 3. Recovery efficiency (REN), agronomic efficiency (AEN) and partial factor productivity (PFPN) of $N$ fertilizer for maize as affected by $N$ treatments and soil types in 2018 and 2019

\begin{tabular}{|c|c|c|c|c|c|}
\hline Soil type & Year & Treatment & $\operatorname{RE}_{\mathbf{N}}(\%)$ & $A E_{N}\left(k k^{-1}\right)$ & $\operatorname{PFP}_{\mathrm{N}}\left(\mathrm{kg} \mathrm{kg}^{-1}\right)$ \\
\hline \multirow{2}{*}{ Sandy soil } & 2018 & $\begin{array}{c}\text { CRU0\% } \\
\text { CRU15\% } \\
\text { CRU30\% } \\
\text { CRU45\% } \\
\text { CRU60\% }\end{array}$ & $\begin{array}{c}14.7 \mathrm{bc} \\
27.5 \mathrm{ab} \\
28.5 \mathrm{a} \\
21.3 \mathrm{abc} \\
12.9 \mathrm{c}\end{array}$ & $\begin{array}{c}12.8 \mathrm{ab} \\
24.0 \mathrm{a} \\
24.6 \mathrm{a} \\
18.3 \mathrm{ab} \\
9.3 \mathrm{~b}\end{array}$ & $\begin{array}{c}42.6 \mathrm{bc} \\
53.8 \mathrm{a} \\
54.3 \mathrm{a} \\
48.1 \mathrm{ab} \\
39.1 \mathrm{c}\end{array}$ \\
\hline & 2019 & $\begin{array}{c}\text { CRU0\% } \\
\text { CRU15\% } \\
\text { CRU30\% } \\
\text { CRU45\% } \\
\text { CRU60\% } \\
\end{array}$ & $\begin{array}{c}56.0 \mathrm{~b} \\
67.0 \mathrm{ab} \\
72.1 \mathrm{a} \\
67.3 \mathrm{ab} \\
64.7 \mathrm{ab} \\
\end{array}$ & $\begin{array}{c}36.1 \mathrm{~b} \\
46.6 \mathrm{a} \\
48.8 \mathrm{a} \\
46.2 \mathrm{a} \\
43.6 \mathrm{ab} \\
\end{array}$ & $\begin{array}{l}59.3 \mathrm{~b} \\
69.8 \mathrm{a} \\
71.9 \mathrm{a} \\
69.4 \mathrm{a} \\
66.7 \mathrm{ab} \\
\end{array}$ \\
\hline \multirow{2}{*}{ Clay soil } & 2018 & $\begin{array}{c}\text { CRU0\% } \\
\text { CRU15\% } \\
\text { CRU30\% } \\
\text { CRU45\% } \\
\text { CRU60\% }\end{array}$ & $\begin{array}{l}12.9 \mathrm{a} \\
26.3 \mathrm{a} \\
26.9 \mathrm{a} \\
24.2 \mathrm{a} \\
22.1 \mathrm{a}\end{array}$ & $\begin{array}{c}5.3 \mathrm{a} \\
10.1 \mathrm{a} \\
11.8 \mathrm{a} \\
10.0 \mathrm{a} \\
9.3 \mathrm{a}\end{array}$ & $\begin{array}{l}58.6 \mathrm{a} \\
63.3 \mathrm{a} \\
65.0 \mathrm{a} \\
63.3 \mathrm{a} \\
62.5 \mathrm{a}\end{array}$ \\
\hline & 2019 & $\begin{array}{l}\text { CRU0\% } \\
\text { CRU15\% } \\
\text { CRU30\% } \\
\text { CRU45\% } \\
\text { CRU60\% } \\
\end{array}$ & $\begin{array}{c}45.6 \mathrm{~b} \\
61.6 \mathrm{a} \\
63.7 \mathrm{a} \\
60.1 \mathrm{a} \\
58.2 \mathrm{ab} \\
\end{array}$ & $\begin{array}{l}28.7 \mathrm{a} \\
34.9 \mathrm{a} \\
36.8 \mathrm{a} \\
35.4 \mathrm{a} \\
33.4 \mathrm{a} \\
\end{array}$ & $\begin{array}{c}72.0 \mathrm{~b} \\
78.2 \mathrm{ab} \\
80.1 \mathrm{a} \\
78.7 \mathrm{ab} \\
76.6 \mathrm{ab} \\
\end{array}$ \\
\hline $\begin{array}{c}\text { ANOVA } \\
\text { Soil type }(\mathrm{S}) \\
\text { Year }(\mathrm{Y}) \\
\mathrm{N} \text { treatment }(\mathrm{N}) \\
\mathrm{S} \times \mathrm{Y} \\
\mathrm{S} \times \mathrm{N} \\
\mathrm{Y} \times \mathrm{N} \\
\mathrm{S} \times \mathrm{Y} \times \mathrm{N}\end{array}$ & & & $\begin{array}{c}\mathrm{ns} \\
* * * \\
* * * \\
* \\
\mathrm{~ns} \\
\mathrm{~ns} \\
\mathrm{~ns}\end{array}$ & $\begin{array}{l}* * * \\
* * * \\
* * \\
\mathrm{~ns} \\
\mathrm{~ns} \\
\mathrm{~ns} \\
\mathrm{~ns}\end{array}$ & $\begin{array}{c}* * * \\
* * * \\
* * * \\
* \\
\mathrm{~ns} \\
\mathrm{~ns} \\
\mathrm{~ns}\end{array}$ \\
\hline
\end{tabular}

Means within each column, soil type and year followed by different letters are significantly different at $\mathrm{P}=0.05$. ns, no significant; $*$ significant at $\mathrm{p}<0.05 ; * * *$ Significant at $\mathrm{p}<0.001$

\section{Discussion}

Numerous studies have indicated that the mixed application of CRU and NU can increased maize yield and NUE, and reduced N loss, such as in North China Plain, Brazil, and the United States (Noellsch et al., 2009; Zheng et al., 2016; Guo et al., 2017; Garcia et al., 2018). Similar result was also found in the present study in Northeast China. Compared with the sole NU application, the mixed application of CRU and NU increased generally maize yield and NUE and reduced $\mathrm{N}$ loss across the contrasting soil types. 
Moreover, the present study determined the optimal mixture ratio of CRU as $30 \%$ for maize in Northeast China, which can synchronously achieve higher yield, NUE and environmental benefits. The optimal mixture ration of CRU for maize were $70 \%$ in both North China and Brazil at the $\mathrm{N}$ rate of $180 \mathrm{~kg} \mathrm{~N} \mathrm{ha}^{-1}$ (Guo et al., 2017; Garcia et al., 2018), which were much higher than that determined in this study, the big difference is mainly associated with the soil types and fertility, climatic conditions, crop yield level and cultivation practices among the various regions. The soil basic fertility and crop yield levels determined the amount of nitrogen fertilizer applied, and climatic conditions and cultivation practices determined the release rate of controlled release urea in the field. The application rate of nitrogen fertilizer and the release rate of controlled release urea in the field determined the optimal mixture ration of controlled release urea and normal urea.

Modern high-yield maize varieties have a larger $\mathrm{N}$ demand, and the sufficient plant $\mathrm{N}$ uptake in the middle-late growth periods are more important for seed development and yield formation (Liu et al., 2014; Guo et al., 2017). The previous studies showed that the percentages of DM and N demand were $47 \%-60 \%$ and $12 \%-32 \%$ for modern high-yield maize, respectively, and the higher post-silking DM and $\mathrm{N}$ uptake are essential to obtain high yield and NUE (Meng et al., 2016). Compared with recommended split N fertilization, the high basal $\mathrm{N}$ fertilization adopted by farmers could not well match the maize $\mathrm{N}$ demand during the growing season, thus causing substantial $\mathrm{N}$ loss at the seedling stage and subsequently insufficient $\mathrm{N}$ supply for reproductive growth and grain yield at the late stage. Moreover, high $\mathrm{N}$ supply at the seedling stage reduce generally root growth and distribution in the deeper soil and thereby limit plant nutrient uptake (Wang et al., 2019). In this study, the total $\mathrm{N}$ loss reached $224 \mathrm{~kg} \mathrm{ha}^{-1}$ by applying sole $\mathrm{NU}$ as basal fertilizer before sowing, which accounting for $60.5 \%$ of the total $\mathrm{N}$ rate. It is necessary to reduce soil available $\mathrm{N}$ level at the early stage while ensure sufficient $\mathrm{N}$ supply at the late stage. This aim could be achieved by applying CRU and NU with an appropriate mixture ratio, in which the mixed CRU delayed $\mathrm{N}$ release at the early stage and provides sufficient $\mathrm{N}$ supply for crop growth at the late stage (Zheng et al., 2016; Guo et al., 2017). In this study, the post-silking percentages of DM and $\mathrm{N}$ uptake were $49 \%$ $59 \%$ and 33\%-41\% in CRU30\% treatment, which were comparable and even higher than those reported by Meng et al. (2016), and thereby improved grain yield and NUE. The mechanism for better performance in the CRU30\% treatment might be related to the optimized root growth and reduced $\mathrm{N}$ loss at the seedling stage by reducing available $\mathrm{N}$ in soil, and the increased $\mathrm{N}$ uptake and plant photosynthetic production because of the sufficient $\mathrm{N}$ supply at the reproductive growth, and subsequent improved yield components at maturity.

Soil and climatic conditions are important factors to affect field crop growth as well as the effectiveness of fertilizer application. In this study, the drought limited seed emergence and maize seedling growth in 2018, therefore showed lower grain yields as compared with those in 2019. Moreover, maize plant growth was also limited on sandy soil due to the lower fertility and poor retention capacity for water and nutrients, and thus obtained significantly lower grain yields relative to the plants grown on clay soil (Feng et al., 2019). In addition to crops, the $\mathrm{N}$ release from fertilizers is also affected by the soil environmental factors. The hydrolysis rate of urea is relatively fast and could be quickly dissolved in soil and converted into available $\mathrm{N}$, which is easily lost if it cannot be effectively maintained in soil or absorbed by crop root. In this study, the sole NU application provided excessive available $\mathrm{N}$ that exceed retention capacity of sandy soil, and thus mass $\mathrm{N}$ was lost might via $\mathrm{NH}_{3}$ volatilization, especially under the rainless 
climate condition in 2018. In this case, maize plant growth would consume the mineralized $\mathrm{N}$ from organic matter at the late stage, and further reduced soil $\mathrm{N}$ contents at harvest. For CRU products, the $\mathrm{N}$ release into soil was delayed or controlled by using envelope technology and thus could effectively reduce N loss (Shavit et al., 1997). However, the $\mathrm{N}$ release rate is considerably affected by environmental factors, especially soil moisture and temperature. Christianson (1988) has found that drought and low temperatures limited $\mathrm{N}$ release from $\mathrm{CRU}$, may cause plant $\mathrm{N}$ deficiency at the early stage. In our study, the $\mathrm{N}$ release of CRU was obviously delayed due to reduced rainfall and soil moisture content, while the $\mathrm{N}$ loss was also reduced and thus could still ensure the soil $\mathrm{N}$ supply at the later stage of maize growth, therefore showed better crop performance in terms of grain yield, NUE and environmental impacts as compared with the sole NU application. Moreover, compared with clay soil, the relatively improving effectiveness of mixed application of CRU and NU was better on sandy soil. However, it should be noted that, in addition to sole NU treatment, the soil Nmin contents in the mixed CRU treatments also showed decreases at harvest on sandy soil due to plant consumption. Hence, the $\mathrm{N}$ fertilizer rate might need to be properly increased on sandy soil when adopting mixed CRU and NU application method, and the optimal $\mathrm{N}$ rate require further investigation in the further researches.

\section{Conclusions}

The results of this study showed that the mixed application of CRU and NU significantly increased the maize yield, aboveground DM accumulation and $\mathrm{N}$ uptake. Among them, the highest maize yields were obtained in CRU30\% treatment, which increased by $24 \%$ on sandy soil and $11 \%$ on clay soil as compared with CRU0\% treatment. Maize plants grown in CRU30\% treatment accumulated more DM and N uptake after silking, which accounted for $49 \%-59 \%$ and $33 \%-41 \%$ of the total DM and $\mathrm{N}$ uptake at maturity, respectively, and thereby increased grain yield and NUE. Compared with CRU $0 \%$ treatment, total $\mathrm{N}$ loss in CRU30\% treatment reduced by $32.3 \%$ and $34.4 \%$ on sandy and clay soils, respectively. In sum, the mixed application of 30\%CRU and 70\% NU was suitable to increase maize yield, NUE and reduce $\mathrm{N}$ loss, which would provide a theoretical basis for the mixed application of CRU and NU and sustainable development of agriculture with rational fertilizing in Northeast China. Researchers should pay more attention to their environmental effects while paying attention to the agronomic and economic effects of the mixed application of controlled release urea and normal urea.

Acknowledgments. This work was supported by the National Key Research and Development Program of China (2016YFD0200403).

\section{REFERENCES}

[1] Burney, J. A., Davis, S. J., Lobell, D. B. (2010): Greenhouse gas mitigation by agricultural intensification. - Proceedings of the National Academy of Sciences 107(26): 12052-12057.

[2] Cassman, K. G., Dobermann, A., Walters, D. T. (2002): Agroecosystems, nitrogen-use efficiency, and nitrogen management. - Ambio 31(2): 132-140.

[3] Chen, X. P., Cui, Z. L., Fan, M. S., Vitousek, P., Zhao, M., Ma, W. Q., Wang, Z. L., Zhang, W. J., Yan, X. Y., Yang, J. C., Deng, X. P., Gao, Q., Zhang, Q., Guo, S. W., Ren, J., Li, S. Q., Ye, Y. L., Wang, Z. H., Huang, J. L., Tang, Q. Y., Sun, Y. X., Peng, X. L., Zhang, J. 
W., He, M. G., Zhu, Y. J., Xue, J. Q., Wang, G. L., Wu, L., An, N., Wu, L. Q., Ma, L., Zhang, W. F., Zhang, F. S. (2014): Producing more grain with lower environmental costs. - Nature 514(7523): 486-489.

[4] China Agriculture Press. (2018): China agriculture yearbook. - China Agric Press, Beijing, China.

[5] Christianson, C. B. (1988): Factors affecting n release of urea from reactive layer coated urea. - Nutrient Cycling in Agroecosystems 16(3): 273-284.

[6] CRGCST (Cooperative Research Group on Chinese Soil Taxonomy). (2001): Chinese Soil Taxonomy. - Science Press, Beijing and New York, pp. 166-167.

[7] Cui, Z. L., Yue, S. C., Wang, G. L., Meng, Q. F., Wu, L., Yang, Z. P., Zhang, Q., Li, S. Q., Zhang, F. S., Chen, X. P. (2013): Closing the yield gap could reduce projected greenhouse gas emissions: a case study of maize production in China. - Global Change Biology 19(8): 2467-2477.

[8] Dobermann, A. (2007): Nutrient use efficiency-measurement and management. - IFA International Workshop on Fertilizer Best Management Practices, Brussels, Belgium.

[9] Douglas, L. A., Riazi, A., Smith, C. J. (1980): A semi-micro method for determining total nitrogen in soils and plant material containing nitrite and nitrate. - Soil Science Society of America Journal 44(2): 431-433.

[10] Drecht, G. V., Bouwman, A. F., Knoop, J. M., Beusen, A. H. W., Meinardi, C. R. (2003): Global modeling of the fate of nitrogen from point and nonpoint sources in soils, groundwater, and surface water. - Global Biogeochemical Cycles 17(4): 1115.

[11] FAO. (2017): FAOSTAT. - Verified 20 April 2018.

[12] Feng, G. Z., Wang, Y., Yan, L., Zhou, X., Wang, S. J., Mi, G. H., Gao, Q., Cui, Z. L. (2019): Effects of nitrogen and three soil types on maize (Zea Mays L.) grain yield in Northeast China. - Applied Ecology And Environmental Research 17(2): 4229-4243.

[13] Galloway, J. N., Townsend, A. R., Erisman, J. W., Bekunda, M., Cai, Z., Freney, J. R., Seitzinger, S. P., Sutton, M. A. (2008): Transformation of the nitrogen cycle: recent trends, questions, and potential solutions. - Science 320(5878): 889-892.

[14] Gao, Q., Li, C. L., Feng, G. Z., Wang, J. F., Cui, Z. L., Chen, X. P., Zhang, F. S. (2012): Understanding Yield Response to Nitrogen to Achieve High Yield and High Nitrogen Use Efficiency in Rainfed Corn. - Agronomy Journal 104(1): 165-168.

[15] Garcia, P. L., González-Villalba, H. A., Sermarini, R. A., Trivelin, P. C. O. (2018): Nitrogen use efficiency and nutrient partitioning in maize as affected by blends of controlled-release and conventional urea. - Archives of Agronomy and Soil Science 64(14): 1944-1962.

[16] Geng, J. B., Chen, J. Q., Sun, Y. B., Zheng, W. K., Tian, X. F., Yang, Y. C., Li, C. L., Zhang, M. (2016): Controlled Release Urea Improved Nitrogen Use Efficiency and Yield of Wheat and Corn. - Agronomy Journal 108(4): 1666-1673.

[17] Guo, J. M., Wang, Y. H., Fan, T., Chen, X. P., Cui, Z. L. (2016): Designing Corn Management Strategies for High Yield and High Nitrogen Use Efficiency. - Agronomy Journal 108(2): 922-929.

[18] Guo, J. M., Wang, Y. H., Blaylockc, A. D., Chen, X. P. (2017): Mixture of controlled release and normal urea to optimize nitrogen management for high-yielding $\left(>15 \mathrm{Mg} \mathrm{ha}^{-1}\right)$ maize. - Field Crops Research 204: 23-30.

[19] Haderlein, L., Jensen, T. L., Dowbenko, R. E., Blaylock, A. D. (2001): Controlled Release Urea as a Nitrogen Source for Spring Wheat in Western Canada: Yield, Grain N Content, and N Use Efficiency. - The Scientific World Journal 1(S2): 114-121.

[20] Kaneta, Y., Awasaki, H., Murai, T. (1994): The non-tillage rice culture by single application of fertilizer in a nursery box with controlled-release fertilizer. - Japanese Journal of Soil Science and Plant Nutrition 65(4): 385-391. (In Japanese).

[21] Kondo, M., Singh, C. V., Agbisit, R., Murty, M. V. R. (2005): Yield Response to Urea and Controlled-Release Urea as Affected by Water Supply in Tropical Upland Rice. - Journal of Plant Nutrition 28(2): 201-219. 


$$
-5382-
$$

[22] Liu, S., Griffiths, S. M. (2011): From economic development to public health improvement: China faces equity challenges. - Public Health 125(10): 669-674.

[23] Liu, J. L., Zhan, A., Bu, L. D., Zhu, L., Luo, S. S., Chen, X. P., Cui, Z. L., Li, S. Q., Hill, R. L., Zhao, Y. (2014): Understanding Dry Matter and Nitrogen Accumulation for HighYielding Film-Mulched Maize. - Agronomy Journal 106(2): 390-396.

[24] Meng, Q. F., Yue, S. C., Hou, P., Cui, Z. L., Chen, X. P. (2016): Improving yield and N use efficiency simultaneously for maize and wheat in China. - Pedosphere 26(2): 137-147.

[25] Noellsch, A. J., Motavalli, P. P., Nelson, K. A., Kitchen, N. R. (2009): Corn response to conventional and slow-release nitrogen fertilizers across a Claypan Landscape. Agronomy Journal 101(3): 607-614.

[26] Page, A., Miller, R., Keeney, D. (1982): Methods of Soil Analysis. Part 2. - American Society of Agronomy. Inc., Madison, WI.

[27] Shavit, U., Shaviv, A., Shalit, G., Zaslavsky, D. (1997): Release characteristics of a new controlled release fertilizer. - Journal of Controlled Release 43(2-3): 131-138.

[28] Shaviv, A. (2001): Advances in controlled-release fertilizers. - Advances in Agronomy 71(1): $1-49$.

[29] Shoji, S., Delgado, J., Mosier, A., Miura, Y. (2001): Use of controlled release fertilizers and nitrification inhibitors to increase nitrogen use efficiency and to conserve air and water quality. - Communications in Soil Science and Plant Analysis 32(7-8): 1051-1070.

[30] Song, C., Guan, Y., Wang, D., Zewudie, D., Li, F. M. (2014): Palygorskite-coated fertilizers with a timely release of nutrients increase potato productivity in a rain-fed cropland. - Field Crops Research 166: 10-17.

[31] Sun, K. G., He, A. L., Hu, Y., Li, B. Q. (2010): Study on the effect of the control released urea in the wheat-corn rotation system. - Chinese Journal of Soil Science 41(5): 1125-1129. (in Chinese).

[32] Tilman, D., Balzer, C., Hill, J., Befort, B. L. (2011): Global food demand and the sustainable intensification of agriculture. - Proceedings of the National Academy of Sciences 108(50): 20260-20264.

[33] Wang, Y., Zhang, X. Y., Chen, J., Chen, A. J., Wang, L. Y., Guo, X. Y., Niu, Y. L., Liu, S. R., Mi, G. H., Gao, Q. (2019): Reducing basal nitrogen rate to improve maize seedling growth, water and nitrogen use efficiencies under drought stress by optimizing root morphology and distribution. - Agricultural Water Management 212(2019): 328-337.

[34] Yan, L., Zhang, Z. D., Zhang, J. J., Gao, Q., Feng, G. Z., Abelrahman, A. M., Chen, Y. (2016): Effects of improving nitrogen management on nitrogen utilization, nitrogen balance, and reactive nitrogen losses in a Mollisol with maize monoculture in Northeast China. - Environmental Science and Pollution Research 23(5): 4576-4584.

[35] Zheng, W. K., Zhang, M., Liu, Z. G., Zhou, H. Y., Lu, H., Zhang, W. T., Yang, Y. C., Li, C. L., Chen, B. C. (2016): Combining controlled-release urea and normal urea to improve the nitrogen use efficiency and yield under wheat-maize double cropping system. - Field Crops Research 197: 52-62.

[36] Zvomuya, F., Rosen, C. J., Russelle, M. P., Gupta, S. C. (2003): Nitrate leaching and nitrogen recovery following application of polyolefin-coated urea to potato. - Journal of Environment Quality 32(2): 480-489. 